\title{
ANALISIS KAUSAL MASA STUDI MAHASISWA PROGRAM STUDI MATEMATIKA UNIVERSITAS ANDALAS DENGAN MENGGUNAKAN METODE CART
}

\author{
Izzati Rahmi 1) \\ Hazmira Yozza 1) \\ 1)Fakultas Matematika dan IImu Pengetahuan Alam, Universitas Andalas \\ e-mail: izzatirahming@sci.unand.ac.id
}

\begin{abstract}
To provide a quality and sustainable education, each study program needs to evaluate the effectiveness and productivity of education, one of which is using indicator of the length of the study. The length of study is influenced by various factors. In this study observations and evaluations of the factors affecting the study period of students of Study Program of Mathematics at Andalas University were conducted by using CART (Classification and Regression Tree) method. The results showed that the most significant factor influencing the length of the study is the Grade Point Average (GPA). Students with high GPA will have a higher chance of graduating on time. Another factor influencing the length of the study is student achievement during high school. Students who consistently perform well (always get the highest rank) when in high school have a high chance of graduating on time. The analysis also showed that students who joined the organization while in high school had a higher chance of graduating on time than those who did not participate. The interesting thing is the students who choose the Study Program of Mathematics at Andalas University as the third choice had a higher chance of graduating on time than the students who choose it as the first or second choice.
\end{abstract}

Keywords: length of study, CART Method

\begin{abstract}
ABSTRAK
Dalam upaya menyelenggarakan pendidikan yang berkualitas dan berkesinambungan, maka setiap program studi perlu melakukan evaluasi terhadap efektifitas dan produktivitas pendidikan, salah satunya dengan menggunakan indikator masa studi. Masa studi mahasiswa dipengaruhi oleh berbagai faktor. Dalam penelitian ini dilakukan analisis terhadap faktor-faktor yang mempengaruhi masa studi mahasiswa Program Studi Matematika Universitas Andalas dengan menggunakan metode CART. Hasil penelitian menunjukkan bahwa faktor yang paling signifikan mempengaruhi masa studi mahasiswa adalah Indeks Prestasi Kumulatif (IPK). Mahasiswa dengan IPK tinggi akan mempunyai peluang lulus tepat waktu lebih tinggi. Faktor lain yang berpengaruh adalah prestasi mahasiswa sewaktu SMA. Mahasiswa yang konsisten berprestasi baik (selalu juara) ketika SMA mempunyai peluang yang tinggi untuk lulus tepat waktu. Hasil analisis juga menunjukkan bahwa mahasiswa yang mengikuti organisasik etika SMA mempunyai peluang lulus tepat lebih tinggi dibandingkan yang tidak ikut organisasi. Suatu hal yang cukup menarik adalah berdasarkan urutan pilihan ketika memasuki perguruan tinngi, kelompok mahasiswa yang memilih Program Studi Matematika Universitas Andalas sebagai
\end{abstract}


pilihan ketiga justru memiliki peluang lulus tepat waktu yang lebih tinggi dibandingkan kelompok mahasiswa yang memilih matematika sebagai pilihan pertama atau kedua.

Kata kunci: masa studi, Metode CART

Masa studi mahasiswa merupakan salah satu indikator yang biasa digunakan untuk mengukur kualitas lulusan perguruan tinggi. Merujuk kepada pedoman akreditasi perguruan tinggi, masa studimerupakan salah satuindikatoruntukmenilaiefektifitas dan produktivitaspendidikan. Perguruan tinggi dituntut untuk mengevaluasi masa studi mahasiswa sehingga dapat menjadi pertimbangan dalam menyusun berbagai program peningkatan efisiensi pendidikan.

Ada banyak faktor yang dapat mempengaruhi masa studi mahasiswa, diantaranya adalah Indeks Prestasi Kumulatif (IPK) mahasiswa ketika menyelesaikan studinya. Semakin tinggi IPK semakin pendek masa studi mahasiswa. Hal ini disebabkan karena mahasiswa dengan IPK lulus yang tinggi, biasanya memiliki Indeks Prestasi (IP) semester yang juga tinggi. IP semester akan menentukan jumlah matakuliah yang dapat diambil mahasiswa yang diukur dengan sistem kredit semester (sks). Dengan demikian mahasiswa dengan IPK tinggi mempunyai kecenderungan untuk menyelesaikan studi lebih cepat (Febrilia, Rahayu, \& Korida, 2016).

Penelitian terdahulu menunjukkan faktor lain yang mempengaruhi masa studi adalah jenis kelamin, dimana perempuan mempunyai kecenderungan untuk lulus tepat waktu dibandingkan lakilaki (Wahyudin, 2006). Hal ini dapat disebabkan oleh adanya kecenderungan bahwa perempuan mempunyai motivasi belajar yang lebih tinggi dibandingkan laki-laki (Anita, 2015). Jalur masuk perguruan tinggi juga mempengaruhi masa studi mahasiswa, dimana hasilp enelitian menunjukkan bahwa mahasiswa reguler punya peluang lebih tinggi untuk lulus tepat waktu dibandingkan mahasiswa non reguler (Samekto, Syafrudie, \& Sutrisno, 2014). Mahasiswa reguler merupakan mahasiswa yang masuk perguruan tinggi melalui jalur PMDK (Penyaluran Minat dan Kemampuan) dan SPMB (Seleksi Penerimaan Mahasiswa Baru). Sedangkan jalur non reguler merupakan jalur khusus yang dilakukan oleh perguruan tinggi untuk menerima mahasiswa secara mandiri. Dalam penelitian ini, akan dianalisis pengaruh IPK, jenis kelamin, jalur masuk perguruan tinggi, terhadap masa studimahasiswa Program Studi Prodi MatematikaUniversitasAndalasmenggunakanMetode CART.

Metode CART merupakan salah satu teknik analisis data yang dapat digunakan untuk melihat hubungan antara satu peubah respon dan beberapa peubah penduga yang meliputi peubah nominal, ordinal maupun kontinu (Breiman, Friedman, \& Olshen, 1984). Beberapa kelebihan metode CART dibandingkan metode lainnya, yaitu hasilnya lebih mudah diinterpretasikan, lebih akurat dan lebih cepat penghitungannya. Selain itu CART bisa diterapkan untuk himpunan data yang mempunyai jumlah observasi besar, peubah yang sangat banyak dan dengan skala peubah campuran melalui prosedur penyekatan biner. Proses penyekatan dilakukan sedemikian sehingga hanya peubah yang signifikan yang terlibat dalam pemodelan. Kelebihan lainnya, metode CART dapat melakukan penataan terhadap peubah penduga berdasarkan kekuatan pengaruhnya terhadap variabel respon (Lewis, 2000).

Metode CART merupakan salah satu dari teknik eksplorasi data berstruktur pohon. Ada dua model pohon yang dihasilkan dalam CART, yaitu pohon regresi yang digunakan untuk peubah respons berupa peubah kontinu dan pohon klasifikasi untuk peubah respons berupa peubah kategorik (Breiman, et al., 1984). Proses pembentukan pohon klasifikasi dilakukan secara rekursif. 
Metode CART diawali dengan melakukan penyekatan biner terhadap simpul induk yang memuat keseluruhan pengamatan yang menghasilkan dua simpul anak. Selanjutnya, setiap simpul anak akan menjadi simpul induk baru yang masing-masing akan disekat lagi menjadi dua simpul anak baru. Proses dilanjutkan hingga diperoleh simpul-simpul yang tidak dapat disekat lagi. Hasil penyekatan pada CART disajikan dalam suatu diagram pohon. Pembentukan pohon klasifikasi dengan metode CART dapat dibagi menjadi 4 tahap sebagai berikut.

a. Tahap Pemilihan Peubah Penyekat

Penentuan peubah penyekat pada setiap simpul dilakukan dengan memilih sekatan terbaik yaitu sekatan yang menghasilkan nilai perubahan impurity (improvement) yang maksimum (Goodness of split). Fungsi impurity yang digunakan untuk simpul $t$, adalah indeks Gini sebagai berikut.

$$
i(t)=\sum_{i \neq j} p(i \mid t) p(j \mid t)
$$

dengan $i(t)$ adalah fungsi impurity dan $p(j \mid t)$ adalah peluang peubah respon kategori ke $j$ pada simpul $t, j=1,2, \ldots, J$ dimana $J$ adalah banyaknya kategori peubah respon. Dalam Breiman et al. (1984) dijelaskan, misalkan $s$ adalah sekatan pada simpul $t, p_{L}$ dan $p_{R}$ masingmasing adalah proporsi amatan yang masuk kesimpul, $t_{L}$ dan $t_{R}$ serta $i\left(t_{L}\right)$ dan $i\left(t_{R}\right)$ masingmasing adalah impurity pada simpul $t_{L}$ dan $t_{R}$, maka perubahan impurity $\Delta i(s, t)$ akibat penyekatan $t$ menjadi $t_{L}$ dan $t_{R}$ oleh sekatan $s$ adalah:

$\Delta i(s, t)=i(t)-p_{L} i\left(t_{L}\right)-p_{R} i\left(t_{R}\right)$

Sekatan terbaik dari himpunan sekatan $S$ adalah sekatan $S^{*}$ yang dapat memaksimumkan perubahan impurity, yaitu:

$$
\Delta i\left(s^{*}, t\right)=\max _{s \in S} \Delta i(s, t)
$$

b. Tahap Penghentian Sekatan

Ada beberapa kriteria untuk menghentikan sekatan. Pertama, berdasarkan nilai perubahan impurity, dimana sekatan dihentikan jika nilai perubahan impurity simpul pada setiap peubah penjelas sudah kecil dari nilai impurity minimum yang telah ditentukan. Kedua, sekatan dihentikan jika pohon yang terbentuk mencapai batas nilai maksimum kedalaman pohon yang ditetapkan. Ketiga, sekatan dihentikan jika ukuran amatan pada simpul induk atau simpul anak kurang dari ukuran minimum yang ditetapkan.

\section{c. Tahap Pendugaan Nilai Peubah Respons}

Dugaan nilai peubah respons dihitung pada setiap simpul akhir yang terbentuk. Nilai dugaan peubah respons untuk setiap simpul akhir $t$ adalah:

$\hat{j}(t)=\max _{j} p(j \mid t)(4)$

dengan $\hat{\jmath}(t)$ nilai dugaan pada simpul akhir $t$. 


\section{METODE}

Data yang digunakan dalam penelitian ini adalah data primer yang diperoleh dari hasil survei terhadap alumni Prodi Matematika Universitas Andalas. Survei dilakukan dari bulan Juli hingga September 2019 melalui penyebaran kuesioner secara online. Teknik sampling yang digunakan adalah purposive sampling dimana setiap alumni Prodi Matematika dapat mengisi kuesioner tersebut. Jumlah alumni yang telah mengisi kuesioner adalah 159 orang.

Dalam penelitian ini faktor-faktor yang mempengaruhi masa studi akan dianalisis dengan model kausal. Masa Studi merupakan peubah respons kategorik yang terdiri dari dua kategori yaitu lulus tepat waktu dan lulus tidak tepat waktu. Kategori lulus tepat waktu adalah bila mahasiswa dapat lulus dalam masa kurang dari atau sama dengan 4 tahun (8 semester). Faktor-faktor yang dianalisis terdiri dari 10 peubah penduga berskala kategorik, dengan rincian sebagai berikut.

1. Asal $\operatorname{SMA}\left(X_{1}\right)$ dibagi dalam 3 kategori, yaitu: (1) Kota Padang, (2) luar Kota Padang dalam propinsi Sumatera Barat, (3) luar Propinsi Sumatera Barat.

2. Nilai Ujian Nasional (UN) Matematika SMA $\left(X_{2}\right)$ dibagi dalam 4 kategori, yaitu: (1) $40-55,(2)$ 5670,(3) 71-85, (4) 86-100.

3. Prestasi akademik di SMA $\left(X_{3}\right)$ dibagi dalam 3 kategori, yaitu: (1) selalu juara, (2) pernah juara, (3) tidak pernah juara.

4. Mata Pelajaran favorit di SMA $\left(X_{4}\right)$ dibagi dalam 3 kategori, yaitu: (1) matematika saja, (2) matematika dan lainnya, (3) tidak suka matematika.

5. Keikutsertaan organisasi di SMA $\left(X_{5}\right)$ dibagi dalam 2 kategori, yaitu: (1) ada dan (2) tidak.

6. Keikutsertaan pada lomba akademik/non akademik $\left(X_{6}\right)$ dibagi dalam 2 kategori, yaitu: (1) ada, (2) tidak ada.

7. Jalurmasukkuliahjurusanmatematika $\operatorname{UNAND}\left(\mathrm{X}_{7}\right)$ dibagikedalam 3 kategori,yaitu: (1) undangan, (2) SBMPTN, (3) mandiri.

8. Urutan pilihan prodi matematika ketika memasuki perguruan tinggi $\left(\mathrm{X}_{8}\right)$ dibagi dalam 3 kategori, yaitu: (1) pertama, (2) kedua, (3) ketiga.

9. Jenis kelamin $\left(X_{9}\right)$ memiliki kategori: (1) perempuan, (2) laki-laki.

10. IPK $\left(X_{10}\right)$ dibagi kedalam 3 kategori yaitu: (1) IPK $<2,5$, (2) 2,5 $\leq \operatorname{IPK} \leq 3,5$, dan (3) IPK $>3,5$.

\section{HASIL DAN PEMBAHASAN}

Hasil analisis data dibagi menjadi dua kelompok yaitu analisis deskriptif dan analisis inferensi dengan menggunakan model pohon klasifikasi. Hasil analisis deskriptif meliputi deskripsi masa studi beserta 10 penduga yang digunakan dalam analisis. Selanjutnya metode CARTditerapkan untuk mengetahui faktor-faktor yang signifikan mempengaruhi masa studi mahasiswa.

\section{a. Hasil Analisis Deskriptif}

Pada Gambar 1 disajikan deskripsi masa studi, yang dibagi menjadi 2 kategori yaitu lulus tepat waktu (jika masa studi $\leq 4$ tahun) dan lulus tidak tepat waktu jika masa studi $>4$ tahun. Pada Gambar 2 terlihat bahwa, dari 159 lulusan hanya 28\% (45 lulusan) yang lulus tepat waktu, sisanya sebanyak $72 \%$ (114 lulusan) lulus tidak tepat waktu. Hal ini menunjukkan bahwa mayoritas mahasiswa matematika Universitas Andalas lulus tidak tepat waktu. 


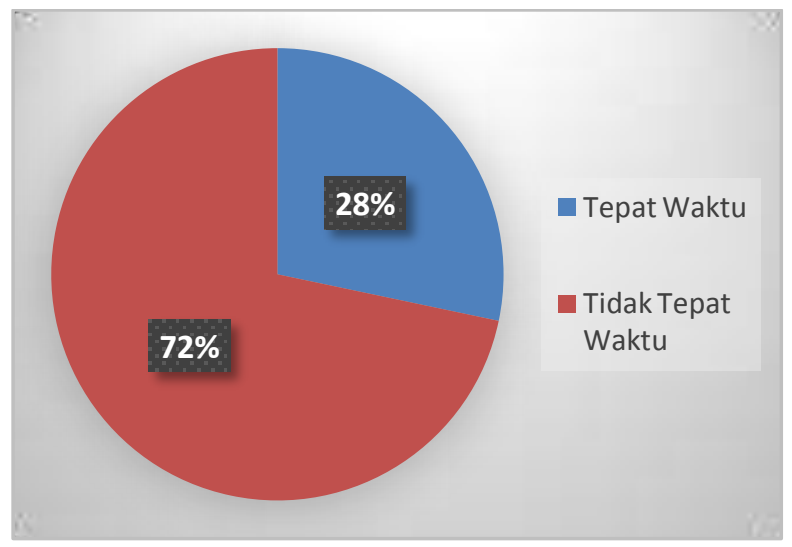

Gambar 1. Deskripsi masa studimahasiswa

Jika dilihat berdasarkan asal SMA, dari 159 responden 29 berasal dari Kota Padang, 84 berasal dari luar Kota Padang dalam Propinsi Sumatera Barat, 31 berasal dari luar Sumatera Barat (Pulau Sumatera), dan 15 berasal dari luar Pulau Sumatera. Pada Gambar 2 menyajikan deskripsi masa studi berdasarkan asal SMA, dimana dapat dilihat bahwa pola sebaran data pada setiap kategori asal SMA menunjukkan pola yang tidak terlalu berbeda.

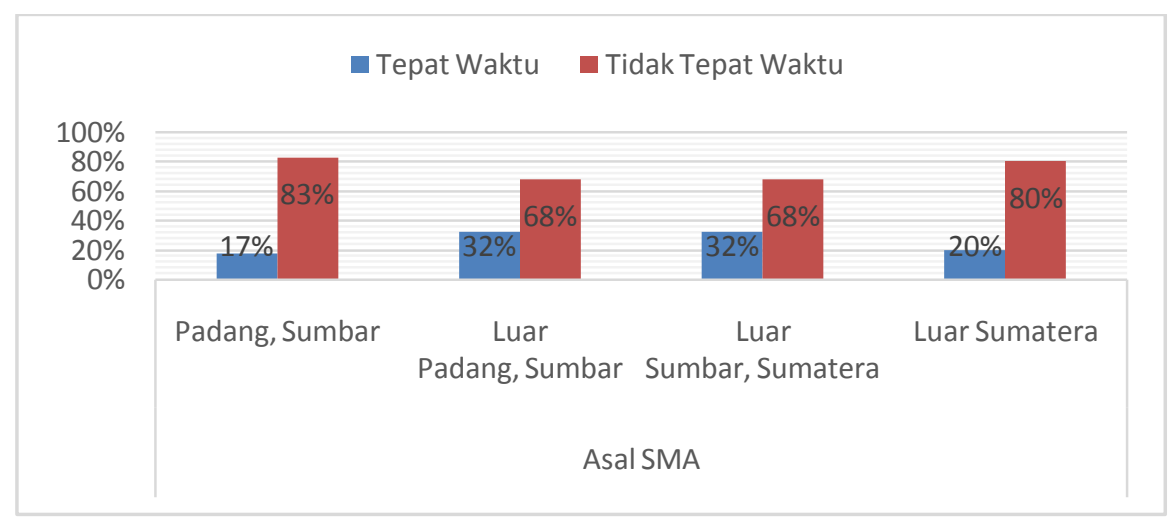

Gambar 2. Deskripsi masa studi berdasarkan asal SMA

Selanjutnya, berdasarkan peubah nilai UN, dari 159 responden terdapat 5 responden dengan nilai UN dalam selang 40-55, 30 orang dalam selang 56-70, 69 dalam selang 71-85, dan 52 orang memiliki nilai UN dalam selang 86-100, dengan catatan nilai UN dibulatkan secara matematis. Pada Gambar 3 disajikan pola sebaran masa studi untuk setiap kategori nilai UN, dimana dapat dilihat bahwa terdapat perbedaan sebaran masa studi untuk keempat kategori, dimana persentase mahasiswa yang tamat tidak tepat waktu lebih banyak terdapat pada mahasiswa dengan nilai UN SMA yang lebih rendah, yaitu pada selang 40-55 dan 71-85. 


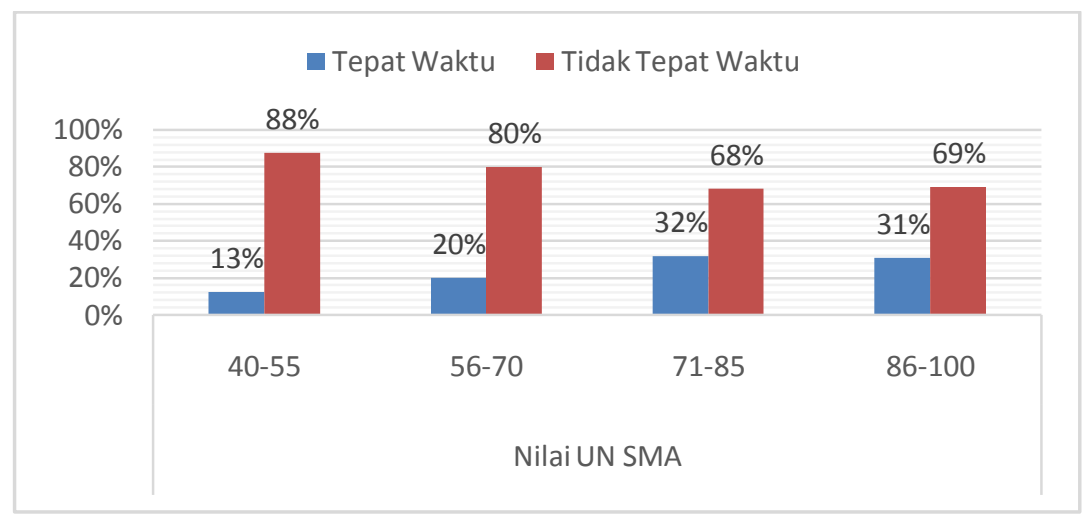

Gambar 3. Deskripsi masa studi berdasarkan nilai UN

Dilihat dari prestasi akademik ketika di SMA terdapat 25 orang yang selalu juara, 71 orang pernah juara dan 63 orang tidak pernah juara. Pada Gambar 4 disajikan pola sebaran masa studi berdasarkan prestasi akademik di SMA. Terlihat bahwa mahasiswa yang pernah juara dengan yang tidak pernah juara memiliki pola sebaran masa studi yang hampir sama, namun kedua kategori ini memiliki pola masa studi yang berbeda dengan mahasiswa yang selalu juara ketika SMA. Mahasiswa yang ketika di SMA selalu juara mempunyai persentase yang lebih tinggi untuk menyelesaikan studi tepat waktu.

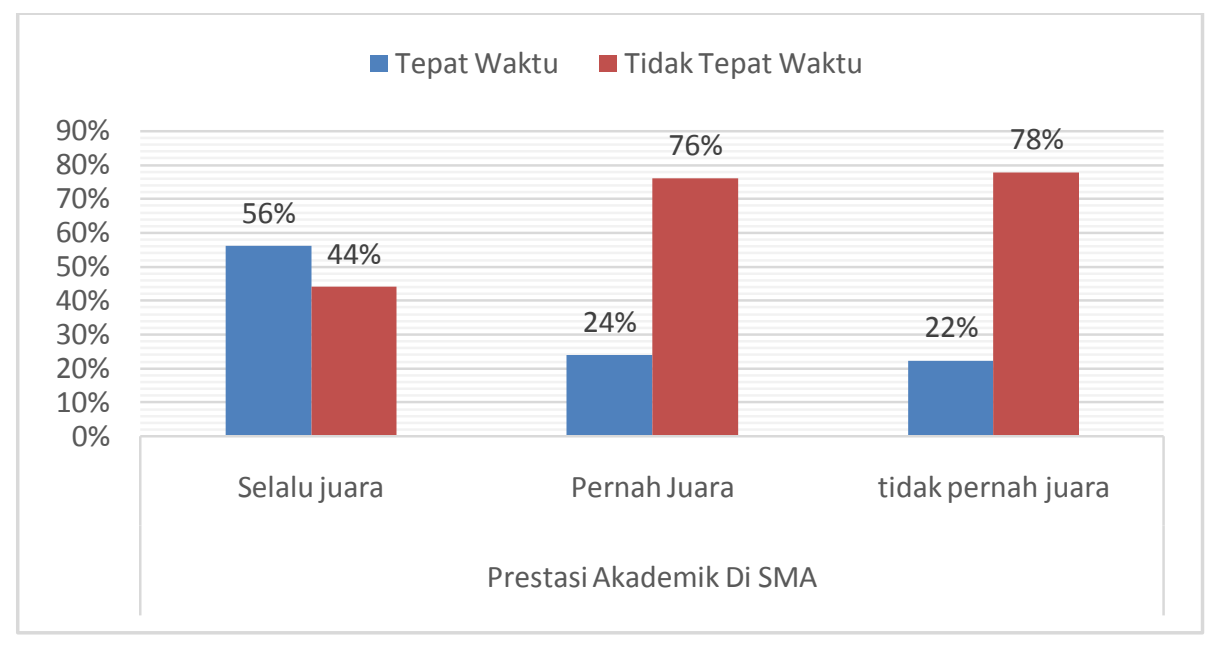

Gambar 4. Deskripsi masa studiberdasarkanprestasiakademik di SMA

Berdasarkan mata pelajaran favorit di SMA, terdapat 45 orang yang menyukai matematika saja, 91 orang menyukai matematika dan lainnya, dan 23 tidak menyukai matematika. Pada Gambar 5 disajikan pola sebaran masa studi berdasarkan matapelajaran favorit di SMA. Terlihat pola sebaran masa studi hampir sama untuk setiap kelompok. 


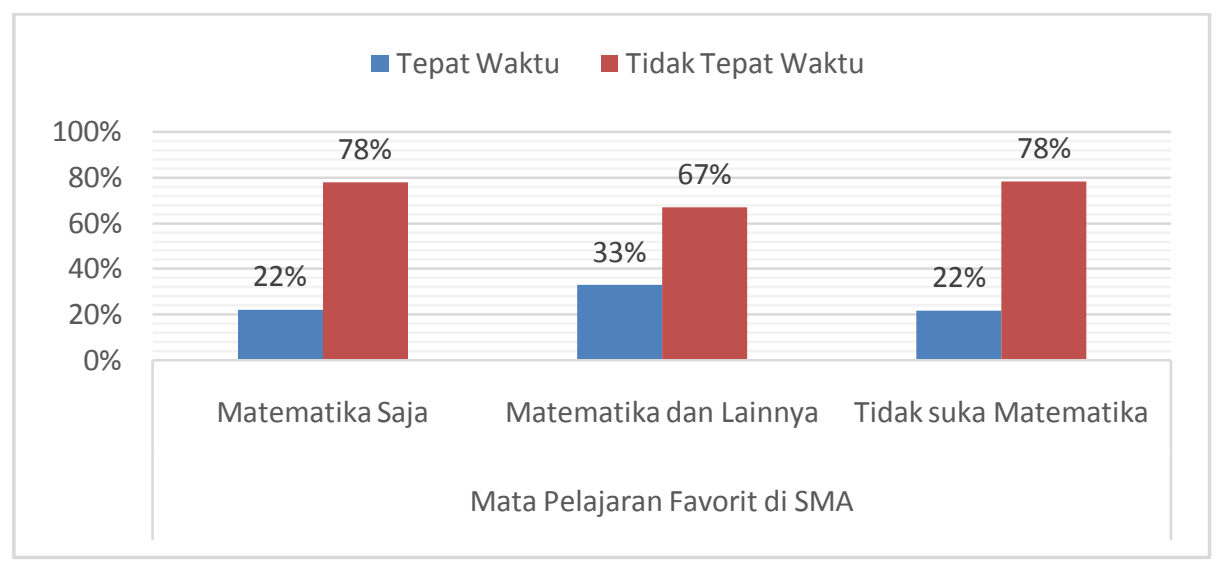

Gambar 5. Deskripsi masa studi berdasarkan matapelajaran favorit di SMA

Berdasarkan peubah keikutsertaan organisasi dapat dilihat bahwa sebagian besar mahasiswa (96 orang) pernah mengikuti organisasi di SMA. Pada Gambar 6 akan disajikan pola sebaran masa studi berdasarkan keikutsertaan organisasi di SMA. Terlihat bahwa mahasiswa yang tidak pernah ikut organisasi mempunyai persentase lulus tidak tepat waktu yang lebih tinggi dibanding mahasiswa yang pernah mengikuti organisasi di SMA.

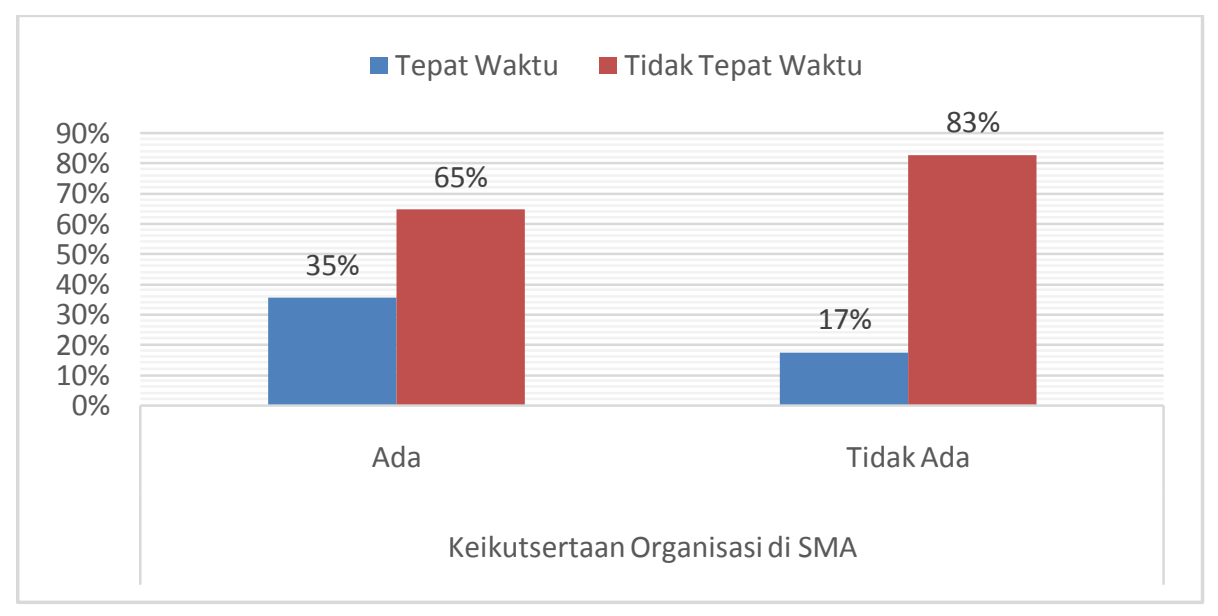

Gambar 6. Deskripsi masa studi berdasarkan keikutsertaan organisasi di SMA

Jika dilihat dari peubah keikutsertaan dalam lomba akademik/non akademik, terdapat 71,06\% (113 orang) dari 159 responden pernah mengikuti lomba. Pada Gambar 7 disajikan pola sebaran masa studi berdasarkan keikutsertaan dalam lomba akademik/non akademik. Terlihat bahwa pola sebaran masa studi hampir sama untuk kedua kelompok tersebut. 




Gambar 7. Deskripsi masa studi berdasarkan keikutsertaan lomba akdemik/non akademik di SMA

Berdasarkan jalur masuk perguruan tinggi (PT), terdapat 49 mahasiswa yang masuk lewat jalur undangan, 88 lewat jalur masuk SBMPTN dan 22 lewat jalu rmandiri. Pada Gambar 8 disajikan pola sebaran masa studi berdasarkan jalur masuk, dimana dapat dilihat bahwa mahasiswa yang masuk melalui jalur undangan dan SBMPTN mempunyai pola masa studi yang hampir sama. Namun, kedua kelompok ini mempunyai pola masa studi yang berbeda dengan mahasiswa yang masuk melalui jalur mandiri. Terlihat bahwa mahasiswa yang masuk lewat jalur mandiri mempunyai persentase lulus tidak tepat waktu yang lebih tinggi.

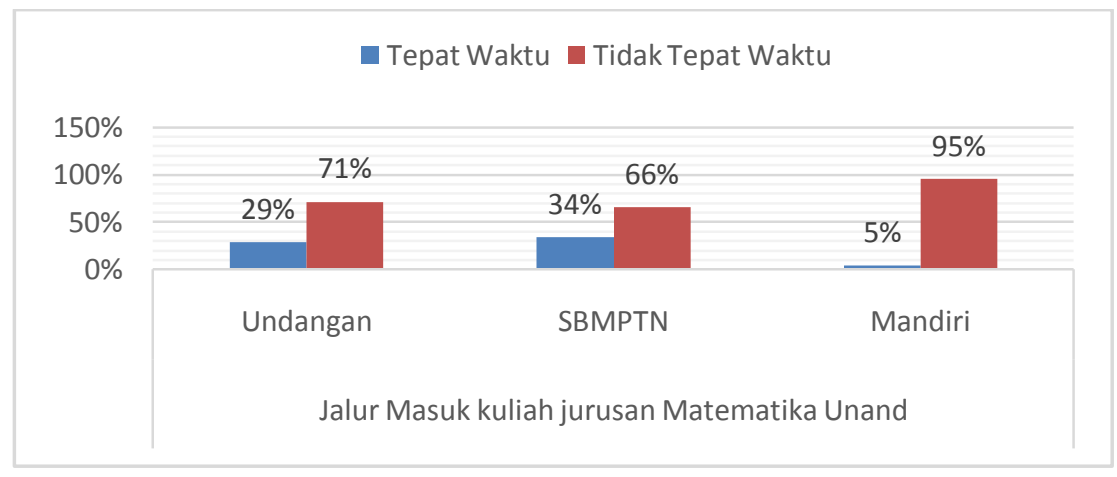

Gambar 8. Deskripsi masa studi berdasarkan jalur masuk PT

Jika dilihat dari peubah urutan pilihan Prodi Matematika ketika memasuki perguruan tinggi, terlihat dari 159 responden ada 70 orang memilih Prodi Matematika sebagai pilihan pertama, 50 orang menjadikan pilihan kedua dan 39 orang memilih Prodi Matematika sebagai pilihan ketiga. Pada Gambar 9 disajikan pola sebaran masa studi berdasarkan urutan pilihan Prodi Matematika. Terlihat bahwa pola sebaran masa studi tidak terlalu berbeda untuk ketiga kelompok tersebut. 


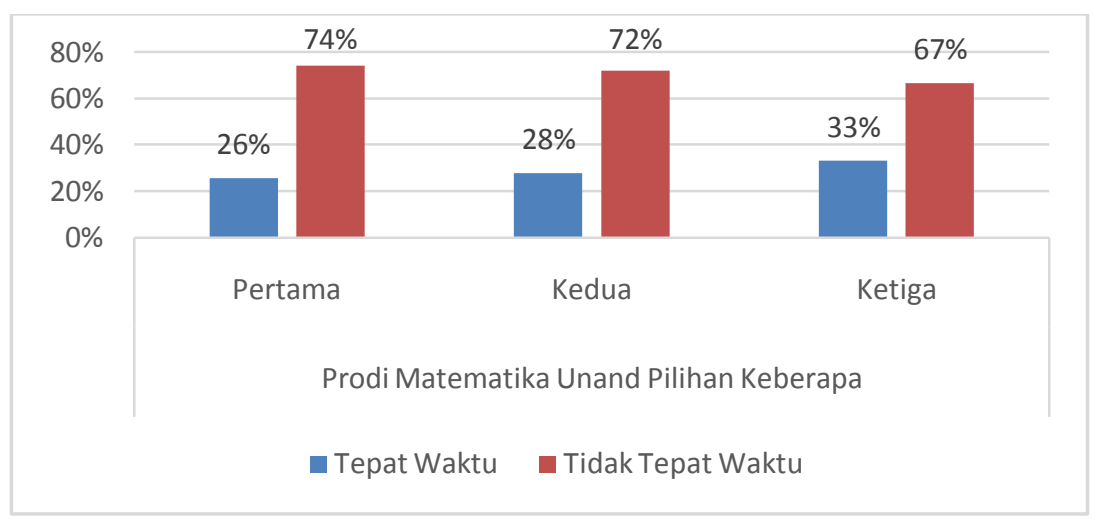

Gambar 9. Deskripsi masa studi berdasarkan urutan pilihan Prodi

Selanjutnya berdasarkan peubah jenis kelamin, $72,96 \%$ besar responden adalah perempuan yaitu sebanyak 116 orang dan selebihnya laki-laki 43 orang. Pada Gambar 10 disajikan pola sebaran masa studi berdasarkan jenis kelamin. Terlihat bahwa pola sebaran masa studi pada kelompok perempuan hampir sama dengan kelompok laki-laki.

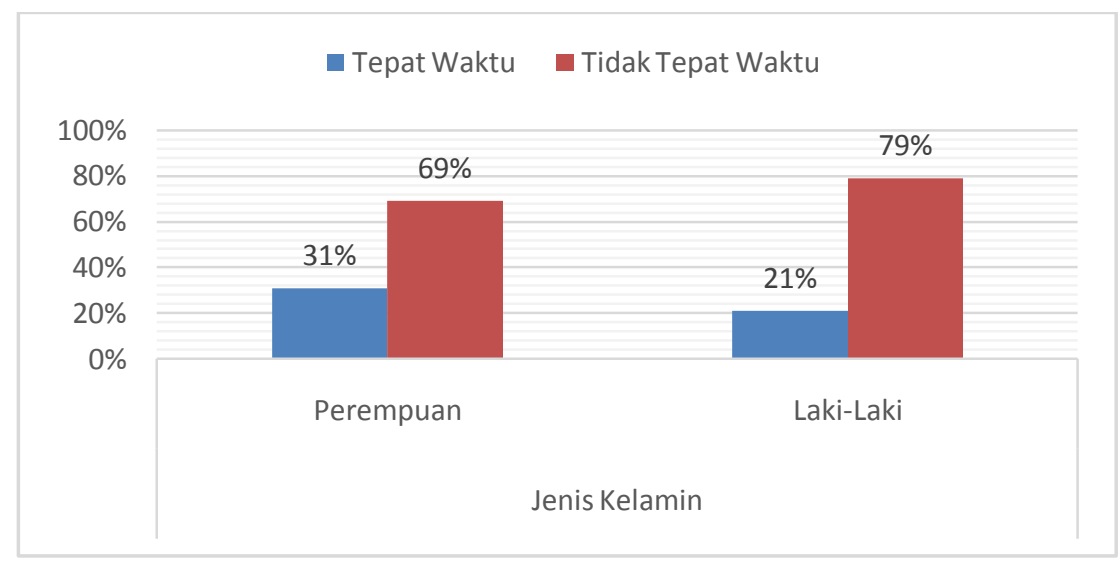

Gambar 10. Deskripsi masa studi berdasarkan jenis kelamin

Berdasarkan peubah IPK, distribusi responden terdiri dari 129 mahasiswa dengan IPK dalam selang 2,5 $\leq$ IPK $\leq 3,5,30$ mahasiswa dengan IPK > 3,5 dan tidak ada mahasiswa yang memiliki IPK $<2,5$. Pada Gambar 11 disajikan pola sebaran masa studi berdasarkan IPK, dimana terlihat perbedaan pola sebaran masa studi. Mahasiswa dengan IPK $>3,5$ mempunyai persentase lulus tepat waktu yang lebih tinggi dibanding mahasiswa dengan $2,5 \leq \mathrm{IPK} \leq 3,5$. 


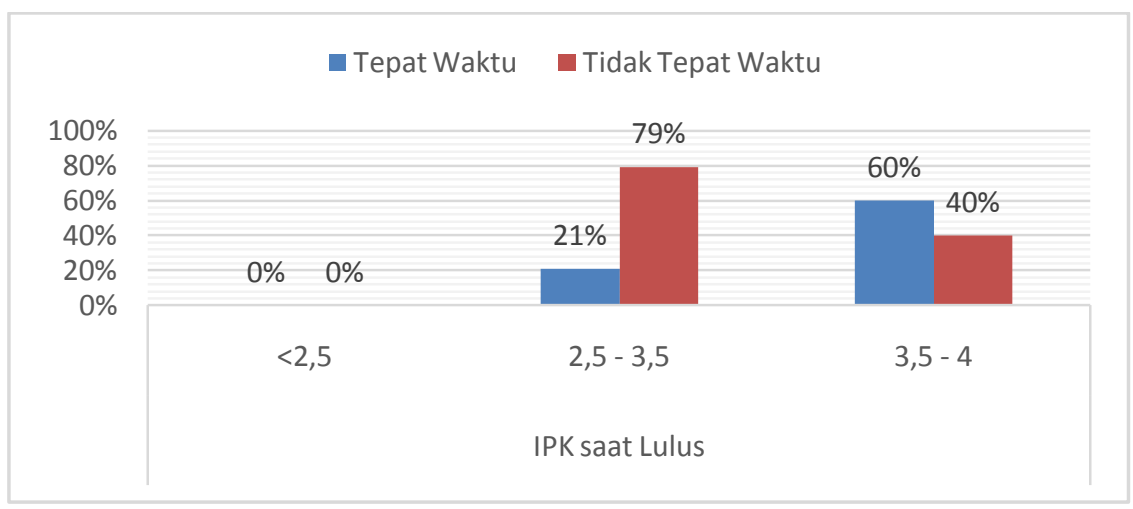

Gambar 11. Deskripsi masa studi berdasarkan IPK

\section{b. Hasil Analisis Metode CART}

Hasil analisis data metode CART disajikan dalam bentuk diagram pohon seperti yang disajikan dalam Gambar 12. Kategori yang muncul pada diagram pohon mengikuti lambang yang tertulis pada bagian metode. Dalam penelitian ini aturan penghentian yang digunakan adalah jumlah amatan pada simpul induk sebesar 60 dan jumlah amatan pada simpul anak sebesar 10. Berdasarkan diagram pohon dapat dilihat bahwa peubah yang pertama muncul sebagai peubah penyekat adalah peubah yang paling signifikan mempengaruhi masa studi. Selanjutnya, peubahpeubah lain yang signifikan mempengaruhi masa studi akan muncul sebagai peubah penyekat pada tahap-tahap berikutnya.

Pada Gambar 12, dapat dilihat bahwa IPK $\left(\mathrm{X}_{10}\right)$ merupakan faktor yang paling signifikan mempengaruhi masa studi. Peubah IPK merupakan peubah ordinal yang terdiri dari 3 kategori yaitu: IPK $<2,5$ (kategori 1), 2,5 $\leq$ IPK $\leq 3,5$ (kategori 2), dan IPK > 3,5 (kategori 3). Pada diagram dapat dilihat bahwa peubah IPK membagi amatan menjadi dua kelompok. Pada kelompok pertama, kelompok IPK kategori 1 dan 2 bergabung menjadi satu kategori gabungan dimana pada diagram muncul dengan kategori $\leq 2$. Artinya kelompok pertama adalah kelompok mahasiswa dengan IPK $\leq$ 3,5 . Sedangkan kelompok kedua adalah kelompok dengan kategori (3), dalam diagram muncul dengan kategori $>2$. Ini berarti kelompok kedua adalah kelompok dengan IPK $>3,5$. Dapat dilihat bahwa mahasiswa dengan IPK $>3,5$ memiliki peluang lulus tepat waktu lebih tinggi. Simpul yang memuat mahasiswa dengan IPK > 3,5 merupakan simpul akhir, artinya pada kelompok ini tidak ada lagi faktor yang mempengaruhi masa studi mahasiswa. Hasil dugaan menunjukkan mahasiswa pada kelompok ini menyelesaikan studi tepat waktu. 


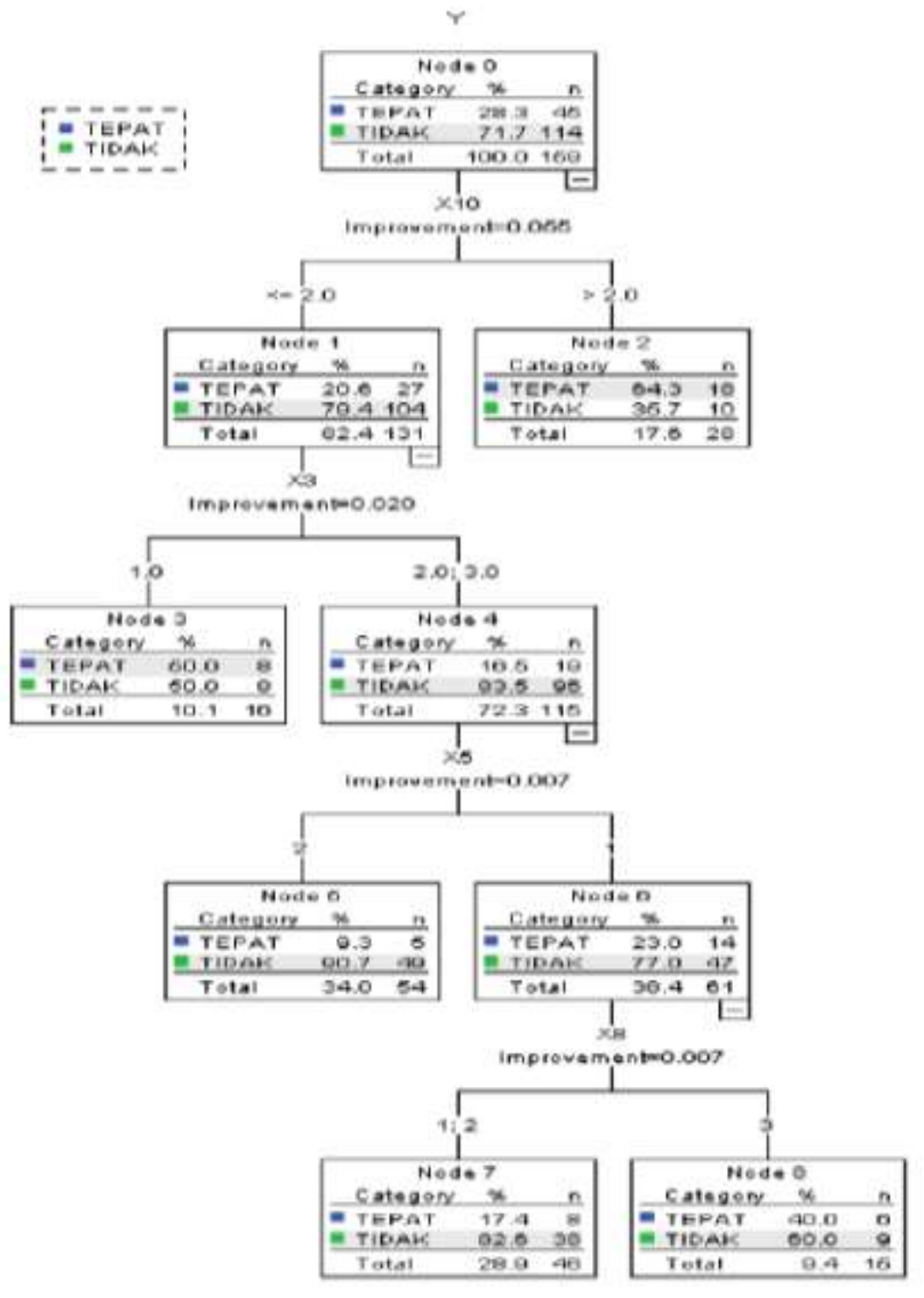

Gambar 12. Diagram Pohon Masa Studi Mahasiswa dengan Metode CART

Faktor berikutnya yang signifikan mempengaruhi masa studi adalah prestasi ketika di SMA $\left(X_{3}\right)$. Peubah ini membagi kelompok mahasiswa dengan IPK $\leq 3,5$ menjadi dua kelompok yaitu kelompok dengan prestasi akademik selalu juara (kategori 1) dan kelompok yang tidak selalu juara (kategori 2) atau tidak pernah juara (kategori 3). Dapat dilihat bahwa mahasiswa yang konsisten selalu juara ketika SMA merupakan kelompok yang mempunyai peluang lulus tepat waktu lebih tinggi. Simpul yang memuat mahasiswa yang selalu juara ketika duduk di bangku SMA adalah simpul akhir, artinya pada kelompok ini tidak ada lagi faktor yang mempengaruhi masa studi mahasiswa. Hasil dugaan pada kelompok mahasiswa yang selalu juara adalah lulus studi tepat waktu.

Selanjutnya kelompok mahasiswa yang tidak selalu juara termasuk yang tidak pernah juara, dipisah menjadi dua kelompok berdasarkan peubah keikutsertaan organisasi ketika di SMA $\left(X_{5}\right)$. 
Hasil analisis menunjukkan bahwa mahasiswa yang ikut organisasi (kategori 1) di SMA punya peluang lulus tepat waktu yang lebih tinggi dibandingkan yang tidak ikut organisasi (kategori 2). Simpul yang memuat mahasiswa yang tidak ikut organisasi merupakan simpul akhir, sehingga pada kelompok ini tidak ada lagi faktor yang mempengaruhi masa studi mahasiswa. Pada kelompok ini dugaan masa studi mahasiswa adalah tidak lulus tepat waktu.

Penyekatan terakhir terjadi pada kelompok mahasiswa yang mengikuti organisasi ketika SMA. Fakto rurutan pilihan Prodi Matematika ketika masuk perguruan tinggi $\left(\mathrm{X}_{8}\right)$ membagi kelompok ini terbagi menjadi dua kelompok yaitu kelompok yang memilih matematika sebagai pilihan pertama (kategori 1) atau pilihan kedua (kategori 2) dan kelompok yang memilih matematika sebagai pilihan ketiga (kategori 3). Terlihat bahwa peluang mahasiswa lulus tepat waktu peluangnya justru lebih tinggi pada kelompok yang memilih matematika sebagai pilihan ketiga. Namun demikian, pada kedua simpul tersebut dugaan masa studi mahasiswa adalah tidak lulus tepat waktu. Hasil ketepatan klasifikasi dengan menggunakan metode CART disajikan pada Tabel 1.

Tabel 1. Ketepatan Prediksi Hasil Klasifikasi

\begin{tabular}{lrrc}
\hline \multirow{2}{*}{\multicolumn{1}{c}{ Pengamatan }} & \multicolumn{3}{c}{ Prediksi } \\
\cline { 2 - 4 } & TEPAT & \multicolumn{1}{c}{ TIDAK } & Persentase Ketepatan \\
\hline TEPAT & 26 & 19 & $57,8 \%$ \\
TIDAK & 18 & 96 & $84,2 \%$ \\
Persentase Keseluruhan & $27,7 \%$ & $72,3 \%$ & $76,7 \%$ \\
\hline
\end{tabular}

Pada Tabel 1, ditunjukkan nilai hit rasio sebesar 76,7\%. Hal ini berarti bahwa prediksi klasifikasi masa studi dengan metode CART memiliki ketepatan sebesar 76,7\%. Dengan demikian metode ini cukup baik digunakan untuk memprediksi masa studi mahasiswa berdasarkan faktor yang signifikan mempengaruhinya, yaituf aktor IPK, prestasi akademik di SMA, keikutsertaan organisasi di SMA dan urutan pilihan Program Studi Matematika ketika masuk perguruan tinggi. Secara umum dapat dilihat bahwa mahasiswa dengan IPK tinggi, selalujuara di SMA dan ikut organisasi di SMA cenderung punya peluang lebih tinggi untuk lulus tepat waktu. Disamping itu, suatu hal yang menarik adalah mahasiswa yang memilih Program Studi Matematika sebagai pilihan ketiga ketika masuk perguruan tinggi, justru memilik peluang lulus tepat waktu yang lebih tinggi dibandingkan yang memilih Program Studi Matematika sebagi pilihan pertama atau kedua.

\section{SIMPULAN}

Hasil analisis menggunaka nmetode CART menunjukkan bahwa faktor-faktor yang mempengaruhi masa studi adalah IPK, prestasi akademik di SMA, keikutsertaan organisasi di SMA dan urutan pilihan Program Studi Matematika ketika masuk perguruan tinggi.

\section{REFERENSI}

Anita, I. W. (2015). Pengaruh motivasi belajar ditinjau dari jenis kelamin terhadap kemampuan berpikir kritis matematis mahasiswa, Jurnal IImu. UPT P2M STKIP Siliwangi, 5(2), 246-251.

Breiman, L., Friedman, J.H., Olshen, R.A., \& Stone. (1984). Classification and regression tree. New York, Chapman and Hall. 
Febrilia, B. R. A., Rahayu, S., \& Korida, B. D. (2016). Ordinal logistic regression analysis of factors affecting the length of student study. Jurnal Mantik, 5(1), 28-34.

Lewis, R. J. (2000). An introduction to classification and regression tree (CART) analysis. The 2000 Annual Meeting of the Society for Academic Emergency Medicine. California.

Samekto,D., Syafrudie, H. A., \& Sutrisno. (2014). Kecenderungan lama studi dan prestasi belajar mahasiswa jalur reguler dan non-reguler program studi pendidikan teknik bangunan. Jurnal Teknologi Dan Kejuruan, 37(2), 153-166.

Wahyudin, D. (2006). Pengaruh kemampuan akademik dan jenis kelamin terhadap lamanya studi mahasiswa menggunakan metode regresi linier berganda. Skripsi. Program Studi Matematika FMIPA Universitas Pakuan, Bogor. 